\title{
Application of Discriminant Analysis to Diagnose the Financial Distress
}

\author{
Rashmi Soni \\ K. J. Somaiya Institute of Management Studies \& Research, Mumbai, India \\ Email: rashmi.soni@somaiya.edu
}

How to cite this paper: Soni, R. (2019) Application of Discriminant Analysis to Diagnose the Financial Distress. Theoretical Economics Letters, 9, 1197-1209. https://doi.org/10.4236/tel.2019.94077

Received: November 28, 2018

Accepted: April 27, 2019

Published: April 30, 2019

Copyright (C) 2019 by author(s) and Scientific Research Publishing Inc. This work is licensed under the Creative Commons Attribution International License (CC BY 4.0).

http://creativecommons.org/licenses/by/4.0/

\begin{abstract}
Prediction of bankruptcy is a critical work. This study is case based research of Ruchi Soya Ltd. to identify the financial distress with the help of last six years data and information. The bankruptcy of the organization can be predicted by using the Altman's $Z$ score model belonging to manufacturing and non-manufacturing and private and public limited firms. This study used discriminant analysis taken the reference of altman's Z score model. Study used various ratios like working capital to total asset, retained earnings to total asset, earnings before interest and tax to total assets, market value of equity to book value of debt and sales to total assets. The analysis conducted on Ruchi Soya Ltd. to identify how and when company identifies the risk of failure. This is a case study method research which satisfies the use of $\mathrm{Z}$ score model to identify the bankruptcy of the company. The secondary data for the assessment were obtained from the financial statement of the company. This study would be used to discuss how to identify the bankruptcy if a firm with the help of Altman's Z score model. Research on financial health using Altman's score is very limited in Indian context. Therefore, this study focuses on applying and interpreting the financial performance of Ruchi Soya Ltd. which files bankruptcy in the year 2017.
\end{abstract}

\section{Keywords}

Risk, Financial Performance, Financial Distress, Altman Analysis, Discriminant Analysis

\section{Introduction}

Profit maximization and Stability of Growth is the main objective of most of the organizations. Best Operational Support and Strong Financial Health required to achieving these objectives the firm. The operational support means internal 
support system like material utilization, labour, effective utilization of funds etc. and external support system like political, social and economic factors. Any mismatch in internal and external support system, results in Bankruptcy of the organization, these failure leads to heavy losses whether financial and non-financial distress.

Whenever companies are not able to pay to their creditors on time that are financially distressed or that are going bankrupt in near future [1]. There are many reasons of bankruptcy like fixed costs are really high; the revenues are low or when the assets cannot be liquidated on time. When the firm's total liabilities exceed total assets or net worth is negative, in this kind of situation one can say that firm is going to be bankrupt. This kind of situation leads to sale reduction, cost increments, losses and not able to face competition. Firm will be under financially distress stage. The financial performance of the company will be distressed and investors and lenders will lose faith on the company. The present study is focused on financial health and distress of Ruchi Soya Ltd., which entered into the Corporate Insolvency Resolution Process because of its total debt of about Rs 12,000 crore which is approx. 12 times of their equity. Taffler, 1983 said, during the financial crises the importance of bankruptcy or financial distress was extremely felt by the stakeholders [2]. Investor's wants to be sure about the credit worthiness and default rate of companies before they invest in them. To help them many bankruptcy models have been developed. Logit analysis, neural network, Altman's Z score model etc., but Altman's is considered to be good and extensively applied by researchers all over the world. This study focuses on applying and interpreting the Altman Z score on Ruchi Soya Ltd. which files bankruptcy in the year 2017. The objective of study is to test the result of $Z$ score model to diagnose the financial distress.

\section{About the Company}

Ruchi Soya established in 1986 [3], has emerged as an integrated player, from farm to fork with secured access to oil palm plantations in India and other key regions of the world. Ruchi Soya Industries Limited [4] is a leading manufacturer and India's largest marketer of healthier edible oils, Vanaspati, premium table spread, and bakery fats and soya food. It was among the top five FMCG players in India. It is one of the highest exporters of soya meal from India.

This company has potential of oil palm cultivation and oil procurement rights to over two lakh hectares of land in India. To sustain its industry leadership the Company has focused on continuous expansion across business verticals. The plants of the company located across India like Indore, Shajapur, Narsinghpur and Mandla in Madhya Pradesh, Mangalore in Karnataka, Raigad and Nagpur in Maharashtra, Haldia in West Bengal, Gandhidham in Gujarat, Thiruvallur in Tamilnadu, Sriganganagar and Bundi in Rajasthan[5]. Ruchi Soya's total debt stood at Rs 12,232 billion nearly 12 times the equity according to their annual report of FY 2017 [1]. In four years, the company's turnover has more than 
halved from Rs 315.61 billion in 2014-15 to Rs 93.75 billion first nine months of 2017-18 as shown in Figure 1. Company's turnover dropped $60 \%$ over the period of four years due to various reasons.

Standard Chartered Bank and DBS Bank, who are the foreign lenders of the company, have filed an insolvency suit against Ruchi Soya Industries at the National Company Law Tribunal (NCLT) on September 2017. The company has informed the exchange about this that the banks have filed applications with NCLT's Mumbai bench to initiate the Corporate Insolvency Resolution Process (CIRP) under the Insolvency and Bankruptcy Code. One of the unsecured creditors had also filed an insolvency case against the company for the recovery of an amount of Rs 9.63 crore in February this year [6].

\section{Literature Review}

Edward Altman [7] established a well-known model for bankruptcy prediction called Altman Z score model. This model also called multiple discriminant analysis model (MDA). He used 66 firms in his first study, half of which were bankrupted. He compared bankrupted and non-bankrupted organizations. He selected five best fit ratios among a large number of ratios for bankruptcy forecasting. The result showed $95 \%$ accuracy one year prior and $72 \%$ two year prior to failure. In 1983 Altman used model for private organizations showed 93\% accuracy rate one year prior and $73 \%$ accuracy two years prior to failure. Green [8] has used financial statements analysis using the ratio analysis as a testing method of financial health of reporting companies. Beaver [9] studied that financial ratio analysis is capable of predicting a firm's performance. Collins [10] used many different models of assessing bankruptcy in his study, but he found that other models are good but Altman's Z score model proves to be better one. Abdullah et al. [11] done a comparative analysis of three different methods of bankruptcy on companies that are financially distressed firms in Malaysia and they found out that the hazard model estimates was most accurate amongst all three methods that was used with accuracy level of $94.9 \%$. Bhunia and Mukhuti [12] used Z-score model on financial distressed Indian companies to predict the bankruptcy and found results with $81 \%$ accuracy in the model.

Venkataramana, Ramakirishnaiah and Azash [13] researched the bankruptcy prediction using three different models using the data of cement companies in the Indian market and found ratio analysis and $\mathrm{Z}$ score is best fit model. Pompe and Bilderbeek [14] observe predictive power of different financial ratios. They

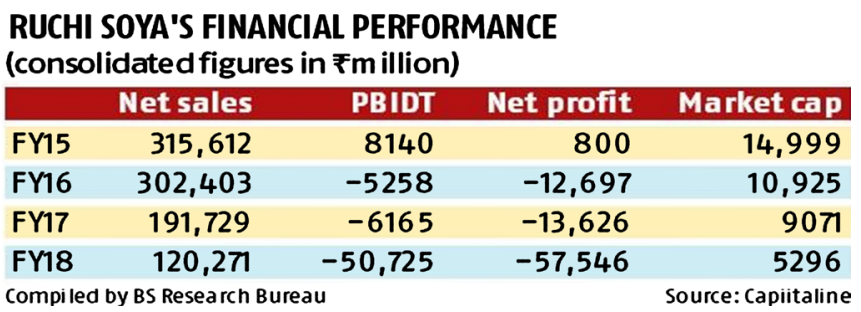

Figure 1. Financial performance. 
studied the different phases of bankruptcy of small and medium size firms and found each and every calculated ratio has indicative power of financial distress. G R Bal and Raja [15] studied the earnings management and techniques used to predict solvency position. Their study uses Z-score to predict financial distress of IOCL and concludes that as per original Z-score the financial position of the company is not that much good. Dr M M Sulphey \& Nisa [16] assessed the solvency position of 220 companies listed in the BSE Small Cap Index using Z score. They analyzed that only 79 companies were in the safe zone. 117 companies were in the grey zone and 24 in the distress zone. The result of the study can be used by potential investors while making investment decisions. Amalendu Bhunia, et al. [17] they studied that capability to detect potential financial problems at a premature stage is absolutely essential because it helps to ensure business, financial, economic and political environment stability. The results show good performance with a highly correct categorization factuality rate of more than $80 \%$. Two ratios were determined significant out of 64 financial ratios utilized in this analysis to discriminate among failed and non-failed companies. Setyani Dwi et al. [18] their study aimed to obtain empirical evidence about the state of financial distress prediction using the Altman Z-score and ratio-ratio test Z-score in influencing the price of shares in the chemical subsectors listed in Indonesia Stock Exchange 2009-2014 period. Ben Chin-Fook Yap et al. [19] they develop a model to improve the predictive abilities for company failures in a later time frame with different financial, business and operating conditions in the Malaysia context. Pongsatat et al. [20] reports the results of a research study examining the comparative ability of Ohlson's Logit model and Altman's four-variance model for predicting bankruptcy of large and small firms in Thailand. The study concludes that while each of the two methods has predictive ability when applied to Thai firms, there is no significant difference in their respective predictive abilities for either large asset or small asset Thai firms.

There are many studies has been done using Altman's Z-score model of predicting bankruptcy. But there are fewer studies in Indian context. This study uses $\mathrm{Z}$ score model to show, how the ratios predict the financial distress and possibility of bankruptcy of the company.

\section{Objectives of the Study}

The study has the following objectives-

- To understand and examine the five key performance ratios suggested by the Altman, of the company

- To apply the Z-Score model of Altman's on calculated ratios and interpret the results

\subsection{Research Methodology and Variables}

This study used discriminant analysis taken the reference of Altman's Z score 
model. The study is exploratory in nature that investigates the different ratios suggested by Altman's Z score model of Ruchi Soya Industries Ltd. This study is based on secondary data collected from the annual reports of last 6 years from 2012 to 2017. The annual report has been downloaded from the company's website. Ruchi Soya Industries Ltd is sample for the study. This company entered into the Corporate Insolvency Resolution Process because of its total debt of about Rs 12,000 crore which is approx. 12 times of their equity. Study used various ratios like working capital to total asset, retained earnings to total asset, earnings before interest and tax to total assets, market value of equity to book value of debt and sales to total assets. The analysis conducted on Ruchi Soya Industries Ltd to identify how and when company identifies the risk of failure.

\subsection{Altman Z Score Model}

At the time of great depression the incidences of default were increasing, one of the professors of Finance of the Leonard N. Stern School of Business of New York University, named Dr Edward I. Altman [21] developed the Financial Model in 1967 to predict the likelihood of bankruptcy of the company which is named as Altman's Z-Score Model. Altman has used five financial ratios to predict a company's probability of failure. This model helps the organization to predict the probability of collapse within 2 years. For this, model Measure Company's health with various financial ratios and then Discriminant analysis used to calculate the $\mathrm{Z}$ score of the company. It is proven to be very accurate to forecast bankruptcy in a wide variety of contexts and markets. This study shows the accuracy of model $72 \%-80 \%$ of predicting bankruptcy.

Revised version of Altman's Z-Score model has been released in 2012 that can be used to evaluate both manufacturing \& non-manufacturing firms \& public \& privative companies in both US \& non-US companies. Application of $Z$ score is not possible to every situation. This model is also used by investors to determine the financial strength and credit risk of the organization before taking decision whether to buy or sell a particular stock. The Altman Z-score is a linear combination of Ratios; four ratios are using Service Firms and five are using Manufacturing firms. The business ratios are weighted by coefficients; the coefficients were estimated by identifying a set of firms which had declared bankruptcy and then collecting a matched sample of firms which had survived, with matching by industry and approximate size. Researchers and analyst being to focus their attention to uses financial Concepts for evaluate corporate financial conditions and performance. These are best useful indicators of a firm's financial situation. The model formed by Altman for predicting a company's financial health is as follows;

THE ORIGINAL Z-SCORE FORMULA OR FOR MANUFACTURING FIRMS

$$
\mathrm{Z}=1.2 \mathrm{X} 1+1.4 \mathrm{X} 2+3.3 \mathrm{X} 3+0.6 \mathrm{X} 4+0.999 \mathrm{X} 5
$$

$\mathrm{X} 1$ = Working Capital/Total Assets 
$\mathrm{X} 2$ = Retained Earnings/Total Assets

X3 = Earnings before Interest and Taxes/Total Assets

$\mathrm{X} 4=$ Market Value of Equity/Total Liabilities

$\mathrm{X} 5=$ Sales/Total Assets

Zones of Discrimination:

\begin{tabular}{cc}
\hline $\mathrm{Z}$ Score & Discrimination \\
\hline $\mathrm{Z}>2.99$ & "Safe" Zone \\
$1.81<\mathrm{Z}<2.99$ & "Gray" Zone \\
$\mathrm{Z}<1.81$ & "Distress" Zone
\end{tabular}

\section{Z-SCORE FORMULA FOR NON-MANUFACTURING FIRMS}

$\mathrm{Z}=6.56 \mathrm{X} 1+3.26 \mathrm{X} 2+6.72 \mathrm{X} 3+1.05 \mathrm{X} 4$

$\mathrm{X} 1=($ Current Assets - Current Liabilities $) /$ Total Assets

$\mathrm{X} 2$ = Retained Earnings/Total Assets

$\mathrm{X} 3$ = Earnings Before Interest and Taxes/Total Assets

$\mathrm{X} 4=$ Book Value of Equity/Total Liabilities

\section{Zones of Discrimination:}

\begin{tabular}{cc}
\hline $\mathrm{Z}$ Score & Discrimination \\
\hline $\mathrm{Z}>2.6$ & "Safe" Zone \\
$1.1<\mathrm{Z}<2.6$ & "Gray" Zone \\
$\mathrm{Z}<1.1$ & "Distress" Zone \\
\hline
\end{tabular}

\subsubsection{X1: Working Capital/Total Assets (WC/TA)}

This ratio is a portion of the liquid assets of the firm compare to the total capitalization. The difference between current assets and current liability is Working capital of the company. It has been observe that if a firm experiencing consistent operating losses have shrinking current assets in relation to total assets. This variable is classified as the liquidity measure of the company. A higher ratio will shows the safe and sound position of the company.

\subsubsection{X2: Retained Earnings/Total Assets}

$\mathrm{RE} / \mathrm{TA}$ ratio used to measure the leverage or profitability of a firm. A growing firm generally indicates high RE/TA as it has built the profits as compared to the infant firms having low earnings. Those firms with high RE, relative to TA, have financed their assets through retention of profits and have not utilized as much debt.

\subsubsection{X3: Profit before Interest \& Taxes/Total Assets (EBIT/TA):}

To calculate the true productivity of the firm's assets, this ratio has been used. EBIT/Ta is independent of any tax or leverage factors. This ratio shows efficiency of earning operating profit from the investments. This is the best ratio to measures the profitability and the productivity. 


\subsubsection{X4: Market Value of Equity/Book Value of Total Liabilities (MVEQUITY/TL)}

This ratio shoes the solvency position of the company. This ratio shows how much more value a firm can lose before its liabilities exceeds its equity value. This is a very important ratio of predicting bankruptcy. When the market value of share is less than the total amount of debt, then the chances of insolvency are generally high and firms are declared bankrupt.

\subsubsection{X5: Revenue/Total Assets (Revenue/TA)}

It is an efficiency ratio which shows the ability of assets to generate sales. This is a competitive measure which tells sales generating capacity of assets under the competitive market conditions. This ratio has unique relationship with other variables in the model, the Sales/Total assets ratio ranks second in its contribution to the overall discriminating ability of the model.

\section{Analysis \& Result}

The present study attempt to explain the concept of Altman's Z Score model and to understand the application of the model on the selected company-Ruchi Soya Ltd. Data has been collected by the annual reports of the company for period of six years, 2012 to 2017. We have collected and calculated all the required variables of $\mathrm{Z}$ score model shown in Table 1 . Working capital is calculated by deducting current assets from current liability, Total assets is total of non-current and current assets of the accompany, for retained earning we have taken profit for the year, EBIT shows earnings after depreciation but before interest and taxes, Market value of equity is calculated, number of outstanding shares multiply by closing market price of share on $31^{\text {st }}$ march of every year. Total liability is total of non-current liability and current liability, for net sales shows revenue from operations. With the help of all collected data we have calculated five ratios of altman's Z score model, working capital to total asset, retained earnings to total asset, earnings before interest and tax to total assets, market value of equity to

Table 1. Required data for Z score calculation.

\begin{tabular}{ccccccc}
\hline & 2012 & 2013 & 2014 & 2015 & 2016 & 2017 \\
\hline CA & $980,181.73$ & $1,135,386.17$ & $925,037.3$ & $1,097,115.59$ & $1,043,787.34$ & $745,197.94$ \\
CL & $938,804.58$ & $1,074,904.96$ & $863,919.51$ & $1,049,998.41$ & $1,299,865.78$ & $1,171,825.09$ \\
WC & $41,377.15$ & $60,481.21$ & $61,117.79$ & $47,117.18$ & $-256,078.44$ & $-426,627.15$ \\
TA & $1,267,919.8$ & $1,442,732.12$ & $1,231,037.66$ & $1,386,918.22$ & $1,645,214.58$ & $1,325,592.73$ \\
RE & $12,231.47$ & $23,626.4$ & 1342.01 & 6092.79 & $-106,158.26$ & $-125,719.78$ \\
EBIT & $74,958.75$ & $61,961.94$ & 56,926 & $47,802.06$ & -4367.37 & $-79,821.75$ \\
MV of Equity & $214,182.8825$ & $127,057.5386$ & $120,423.7351$ & $93,536.91816$ & $63,479.13718$ & $62,142.73429$ \\
Total Liability & $1,206,109.46$ & $1,047,751.92$ & $997,192.43$ & $1,166,156.21$ & $1,397,873.97$ & $1,223,222.11$ \\
Net sales & $2,599,660.27$ & $2,616,031.82$ & $2,438,101.48$ & $2,830,907.88$ & $2,769,238.67$ & $1,852,689.74$ \\
\hline Source: Calculated by author. & & & & &
\end{tabular}


book value of debt and sales to total assets. The analysis conducted on last six years of data of Ruchi Soya Ltd to identify how and when company identifies the risk of failure. This is a case study method research which satisfies the use of $\mathrm{Z}$ score model to identify the bankruptcy of the company (Figure 2).

\section{X1: Working Capital/Total Assets (WC/TA)}

Ruchi Soya requires more working capital because it manufactures and supplier to consumer goods makers and doesn't sell directly to consumers [6] (Figure 2). Their payment period is relatively long. To manage the shortfall in working capital the company used to take short term debt. Above graph 1 \& 2 shows that working capital of Ruchi Soya was positive till 2015 and suddenly in the year 2016 and 2017 company had lots of short term debts results to negative working capital. The company failed to pay debt as it couldn't recover its receivables on time. The working capital to total assets shows the liquidity position of the company. Suppliers always wants to work with the company who has positive WC/TA ratio, Ruchi Soya had good liquidity till 2015 but year 2016 \& 2017 negative ratio indicates cash flow difficulties of the company and they were not able to pay to its supplier, creditors and lenders.

\section{X2: Retained Earnings/Total Assets:}
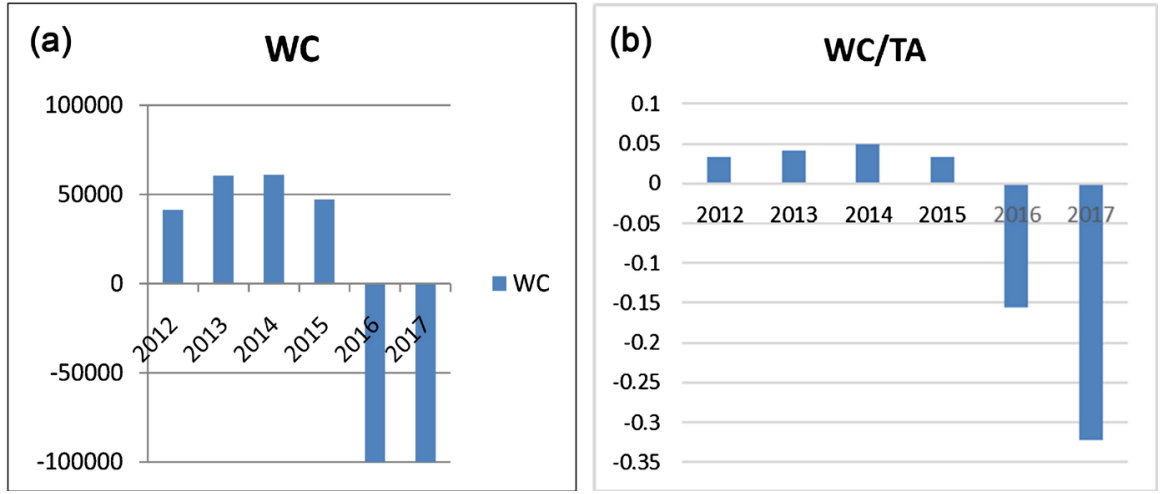

Source: Prepared by compiled data of the company.

Figure 2. (WC/TA).

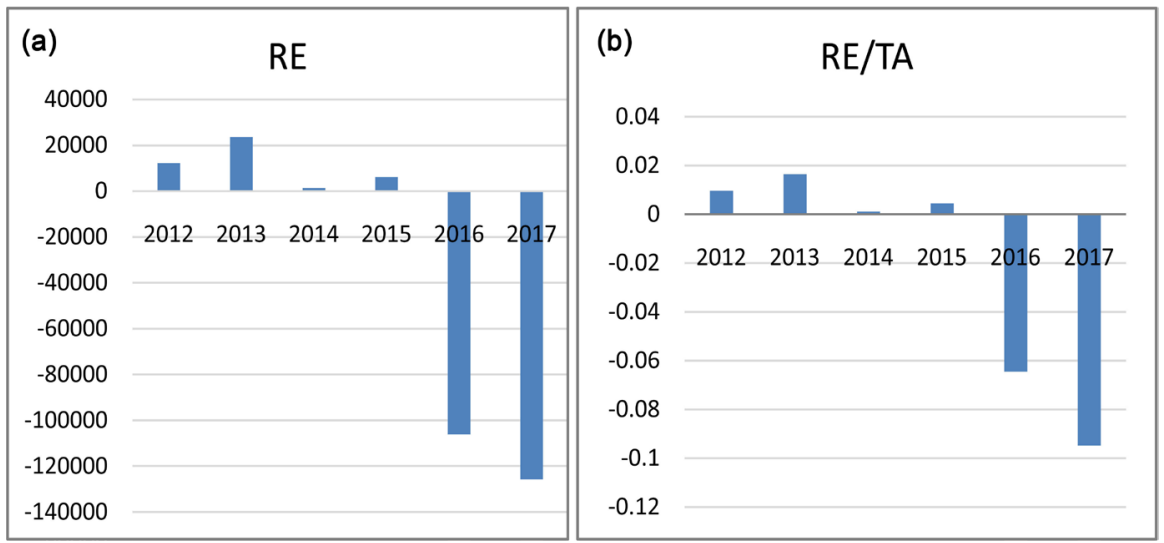

Source: Prepared by compiled data of the company.

Figure 3. (RE/TA). 
Retained earnings to total assets signify that how much portion of total assets is financed by retained earnings (Figure 3). If company has sufficient amount of retained earnings then generally they use internal funds to finance assets and new projects. It has no cost. A falling ratio indicates that profit from operating activity is low in the company which we can see in the Figure 3.

The profitability of the firm was positive till 2015, it has good growth rate. In the year 2016 and 2017 company has huge loss due to heavy interest cost. The company bet on castor seeds as prices rose as high as Rs 5000 a quintal in the year 2015 and they did not hedge the exposure as well. 2016 company faced weak global demand and fewer monsoons [6].

\section{X3: Profit before Interest \& Taxes/Total Assets:}

This ratio shows the true productivity of the firm assets (Figure 4). This is the most significant factor in the Altman Z_Score model. Profit before Interest \& Taxes/Total Assets indicate the operating performance and productivity of the assets of the company. In the study period of six years, the company is having EBIT in reduction phase. This ratio used in assessing the risk of corporate failure as well. Ruchi Soya was facing decreasing EBIT since 2013 and negative in the year 2016 and 2017 shown in graph 5 \& 6. Low EBIT/Ta ratios indicate that company was not able to use assets to generate returns and may be the company has to reduce some operating expenses. In the year 2017 company's total assets were reduced and operating loss was increased. From 2012 onwards the company's position was not good.

\section{X4: Market Value of Equity/Book Value of Total Liabilities:}

Market Value of Equity to Total Liabilities is the indicator of insolvency (Figure 5). This ratio shows that how much the firm's assets can decline in value before the liabilities exceed the assets and the firm becomes bankrupt. This ratio is very much relevant for the owners and investors. It shows how any change in financial performance will react in market.

From the analysis, it can be seen that company has more liability compare to $\mathrm{MV}$ of equity. Market value of equity is calculated based on number of outstanding

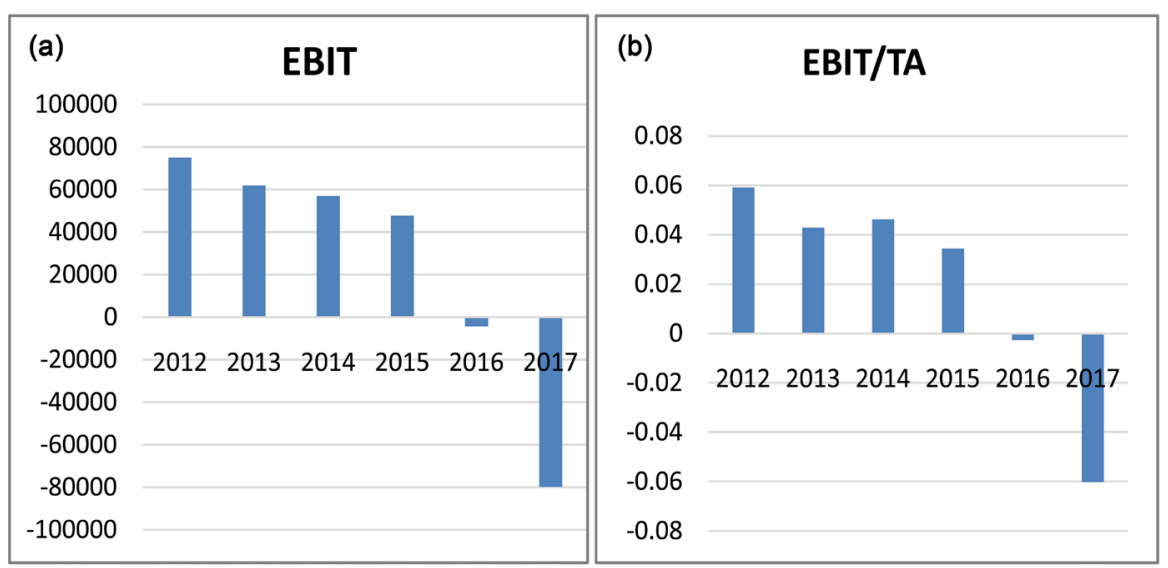

Source: Prepared by compiled data of the company.

Figure 4. (EBIT/TA). 
shares and market price of the shares. For the calculation, closing price on $31^{\text {st }}$ march of every year has been taken. The market price of share on $31^{\text {st }}$ March 2012 to 2017 was Rs $64.25,38.05,36.05,28,19,18.6$ and 5.65 approx. was noted from the Bombay Stock exchange website. From the calculation it can be concluded that Ruchi Soya has more debt than equity which shows in graph 7 \& 8 . They have not issued any further equity in the study period. Market Value of Equity/Book Value of Total Liabilities ratio of Ruchi Soya clearly show the dangerous situation of the company.

\section{X5: Revenue/Total Assets (Revenue/TA):}

This ratio measures the efficiency of assets to generate sales (Figure 6). The sales are very important indicator of showing the overall performance of the company. Ultimate performance of the company depends on sales revenue. Revenue to Total Assets shows the turnover ratio. Higher turnover is always better; it shows that the company is using its assets more efficiently. Ruchi Soya has comparatively consistent total assets and sales revenue during the study period. In the year 2017 company's revenue has decreased because of the bankruptcy case. From the year 2012 to 2015 company has turnover of 2 times but in the year 2016 and 2017 assets turnover reduced to 1.6 and 1.3 respectively as shown in graph $9 \& 10$. This indicates that the company is gradually decreasing utilization of its assets in inefficient manner to generate sales.

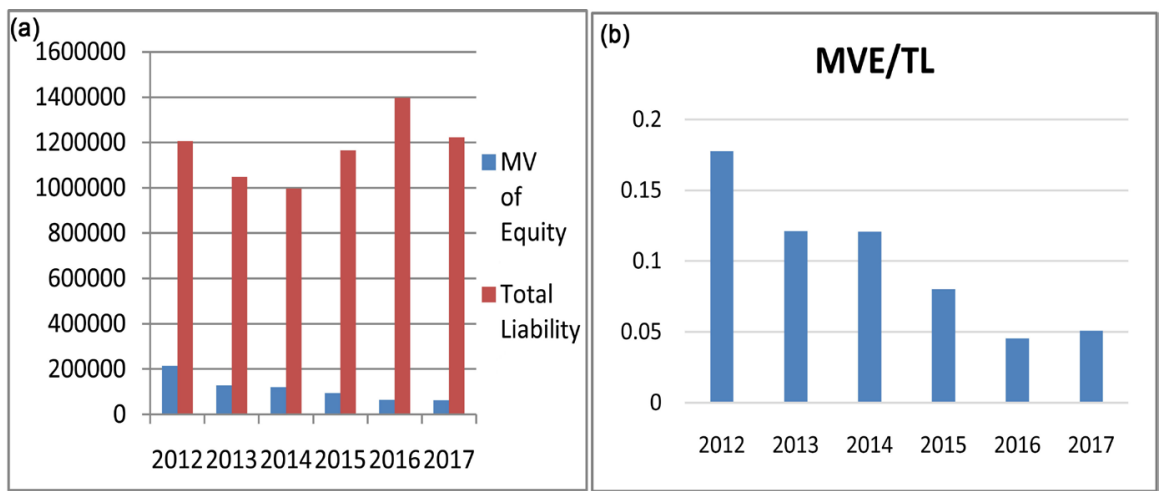

Source: Prepared by compiled data of the company.

Figure 5. (MVEQUITY/TL).
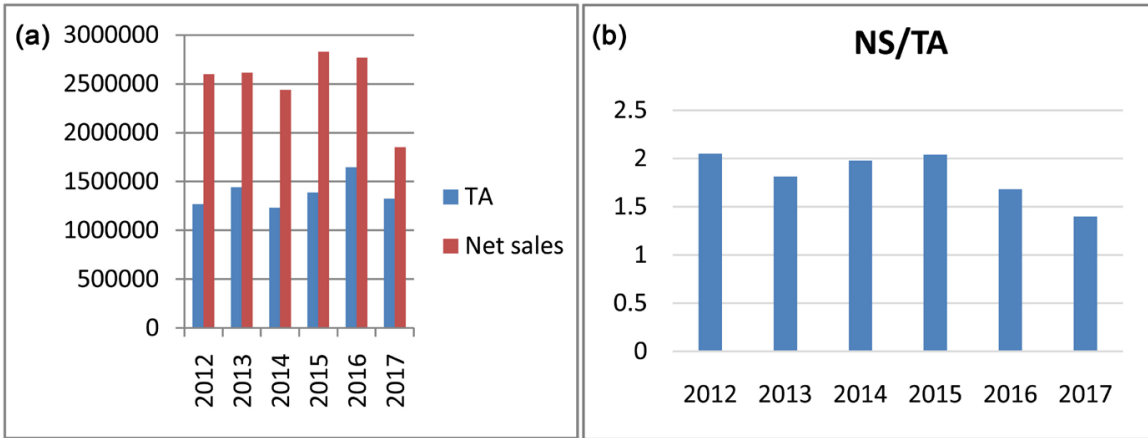

Source: Prepared by compiled data of the company.

Figure 6. (Revenue/TA). 


\section{Analysis \& Result}

Dr. Altman, $\mathrm{Z}$ score explained an important issue of the time, how best we can predict the failure of the business in future and can take corrective actions. $\mathrm{Z}$ score model has five ratios which we have calculated and discussed above. Altman has used statistical method to calculate the $\mathrm{Z}$ score of the company. He gave different weights to the five ratios that is called coefficient. We have used his formula of Z-Score $(1.2 \mathrm{X} 1+1.4 \mathrm{X} 2+3.3 \mathrm{X} 3+0.6 \mathrm{X} 4+0.999 \mathrm{X} 5)$ and calculated score for year 2012 to 2017 for the Ruchi soya. The company was in Gray Zone since 2012 to 2015 and in distress zone in the year 2016 and 2017 as shown in Table 2.

Its troubles began much before 2012. They got hit by unfavorable duty structures for its largest edible oil refining business, and two successive below-average monsoons. They are supplier to makers of refined oil to shampoos. The company had a long working capital cycle, which required lots of cash. They had lots of short term debt to fulfill its working capital requirements. Ruchi Soya is a agro-processing company, it operates on thin margins. An unfavorable duty structure in domestic and international markets hurt the company even more [22].

\section{Conclusions \& Recommendations}

This study would be used to explain the application of Altman's Z Score model. The objective was to investigate the accuracy of Altman's models in predicting corporate financial distress. It is recognized that the Altman's model can be used in Ruchi soya Industries Limited to forecast the possibility of bankruptcy. This

Table 2. Value of coefficient and Z Score of Ruchi Soya Industries Ltd.

\begin{tabular}{|c|c|c|c|c|c|c|c|}
\hline Factor & $\mathrm{X} 1$ & $\mathrm{X} 2$ & $\mathrm{X} 3$ & $\mathrm{X} 4$ & $\mathrm{X} 5$ & Z Score & Discrimination \\
\hline coefficient & 1.2 & 1.4 & 3.3 & 0.6 & 1 & & \\
\hline \multirow[t]{2}{*}{2012} & 0.032634 & 0.009647 & 0.059119 & 0.177582 & 2.050335 & & \\
\hline & 0.039161 & 0.013506 & 0.195094 & 0.106549 & 2.050335 & 2.404644 & Gray Zone \\
\hline \multirow[t]{2}{*}{2013} & 0.041921 & 0.016376 & 0.042948 & 0.121267 & 1.813248 & & \\
\hline & 0.050306 & 0.022927 & 0.141727 & 0.07276 & 1.813248 & 2.100968 & Gray Zone \\
\hline \multirow[t]{2}{*}{2014} & 0.049647 & 0.00109 & 0.046242 & 0.120763 & 1.980526 & & \\
\hline & 0.059577 & 0.001526 & 0.1526 & 0.072458 & 1.980526 & 2.266686 & Gray Zone \\
\hline \multirow[t]{2}{*}{2015} & 0.033973 & 0.004393 & 0.034466 & 0.08021 & 2.04115 & & \\
\hline & 0.040767 & 0.00615 & 0.113739 & 0.048126 & 2.04115 & 2.249932 & Gray Zone \\
\hline \multirow[t]{2}{*}{2016} & -0.15565 & -0.06453 & -0.00265 & 0.045411 & 1.683208 & & \\
\hline & -0.18678 & -0.09034 & -0.00876 & 0.027247 & 1.683208 & 1.424579 & Distress Zone \\
\hline \multirow[t]{2}{*}{2017} & -0.32184 & -0.09484 & -0.06022 & 0.050802 & 1.397631 & & \\
\hline & -0.38621 & -0.13278 & -0.19871 & 0.030481 & 1.397631 & 0.710417 & Distress Zone \\
\hline
\end{tabular}

Source: Calculated by author. 
company's z score result in the year 2012 to 2015 have gray zone and after that in the year 2016 and 2017 was in distress zone. It shows that company was facing financial problems since long and management were not able to cope up with those issues. The market value of the firm and the assets turnover ratio is significant in $\mathrm{z}$ score model.

In addition to these results and findings, there are also some limitations present in the study that must be considered while interpreting the results and conclusion. This study is only for one company and for last six years of data so the results and findings of this study cannot be generalized over any other study with different sample and time period. It is based on financial statement data; if data given is wrong then analysis also proves to be wrong.

\section{Recommendations}

The Z Score is not intended to predict when a firm will actually file for legal bankruptcy. It is instead a measure of how closely a firm resembles other firms that have filed for bankruptcy, i.e. it tries to assess the likelihood of economic bankruptcy. In this study we have tested that how we can use Altman Z score method to check the financial soundness of the company and if company comes in grey zone then management needs to take corrective actions. Ruchi Soya being a supplier to makers of refined oil to shampoos, the company had a long working capital cycle, leaving it short of cash. Short-term borrowings to tide over the crunch eventually left it under a pile of debt and the company eventually failed to pay debt as it couldn't recover its receivables. They stemmed from unfavorable duty structures for its largest edible oil refining business, and two successive below-average monsoons that hurt seed extraction the second-biggest revenue contributor. The firm needs to plan for Sales Maximization, Operating Income Maximization, maximizing the market value and Manage Sufficient Working Capital For Making Better Z score Value. Finally we can conclude that Altman's model still exists and used by the companies for measuring creditworthiness of the companies and it still remains promising but challenging.

\section{Conflicts of Interest}

The author declares no conflicts of interest regarding the publication of this paper.

\section{References}

[1] https://www.thehindubusinessline.com/profile/author/Our-Bureau

[2] Taffler, R.J. (1983) The Assessment of Company Solvency and Performance Using a Statistical Model: A Comparative UK Based Study. Accounting and Business Research, 13, 295-307. https://doi.org/10.1080/00014788.1983.9729767

[3] http://www.ruchisoya.com/RSIL_AR_2017-18.pdf

[4] http://rakesh-jhunjhunwala.in/forum/threads/ruchi-soya-industries-ltd-cmp-26-tur naround.3009/\#post-24630

[5] https://corporatefinanceinstitute.com/resources/knowledge/finance/insolvency 
[6] https://www.bloombergquint.com/stock/820800/ruchi-soya-industries-ltd

[7] Altman, E. (1968) Financial Ratios, Discriminant Analysis and the Prediction of Corporate Bankruptcy. Journal of Finance, 23, 589-609.

https://doi.org/10.2307/2978933

[8] Green, D. (1978) To Predict Failure, Management Accounting. 39-45.

[9] Beaver, W.H. (1966) Financial Ratios as Predictors of Failure. Journal of Accounting Research, 4, 71-111. https://doi.org/10.2307/2490171

[10] Collins, R.A. (1980) An Empirical Comparison of Bankruptcy Prediction Models. Financial Management, 9, 52-57. https://doi.org/10.2307/3665168

[11] Abdullah, et al. (2008) Predicting Corporate Failure of Malaysia's Listed Companies Comparing Multiple Discriminant Analysis Logistic Regression and the Hazard Model. International Research Journal of Finance and Economics, 15, 201-217.

[12] Bhunia, K.M. (2011) Prediction of Financial Distress-A Case Study of Indian Companies.

https://www.researchgate.net/publication/215869253_Prediction_of_Financial_Dist ress_-A_Case_Study_of_Indian_Companies

[13] VenkataRamana, N., et al. (2012) Financial Performance and Predicting the Risk of Bankruptcy: A Case of Selected Cement Companies in India. International Journal of Public Administration and Management Research, 1, 40-56.

[14] Pompe and Bilderbeek, J. (2005) The Prediction of Bankruptcy of Small- and Medium-Sized Industrial Firms. Journal of Business Venturing, 20, 847-868. https://doi.org/10.1016/j.jbusvent.2004.07.003

[15] Bal, G.R., Rao, N. and Raja, S. (2013) Evidences of Financial Shenanigans from Past and Techniques to Predict Earnings Management and Solvency Position: A Case Study of IOCL. The Orrisa Journal of Commerce, 34. https://doi.org/10.2139/ssrn.2208368

[16] Sulphey, M.M. and Nisa, S. (2013) The Analytical Implication of Altman's Z Score Analysis of BSE Listed Small Cap Companies. Journal of Commerce and Management Perspective, 2, 145-155.

[17] Bhunia, A., et al. (2011) Prediction of Financial Distress-A Case Study of Indian Companies. Asian Journal of Business Management, 3, 210-218.

[18] Lestari, S.D., et al. (2016) Financial Distress Prediction with Altman Z-Score and Effect on Stock Price: Empirical Study on Companies Subsectors Chemical Listed in Indonesia Stock Exchange Period 2009-2014. International Journal of Business and Management Invention, 5, 30-39. http://www.ijbmi.org

[19] Yap, B.C.-F., et al. (2010) How Well Do Financial Ratios and Multiple Discriminant Analysis Predict Company Failures in Malaysia. International Research Journal of Finance and Economics, 54, 166-174.

[20] Pongsatat, S., Ramage, J. and Lawrence, H. (2004) Bankruptcy Prediction for Large and Small Firms in Asia: A Comparison of Ohlson and Altman. Journal of Accounting and Corporate Governance, 1, 1-13.

[21] Altman, E. (2003) Financial Ratios, Discriminant Analysis, and Prediction of Corporate Bankruptcy. Journal of Finance, 23, 589-610. https://doi.org/10.2307/2978933

[22] https://www.business-standard.com/article/companies/ruchi-soya-s-rp-seeks-8-10days-to-reply-on-issues-raised-by-patanjali-118062200555_1.html 